\title{
Exploring the Origin of Mathematical Economics*
}

\author{
Balbir S. Sihag \\ University of Massachusetts Lowell, Lowell, USA \\ Email: balbir_sihag@uml.edu
}

Received 14 January 2016; accepted 13 February 2016; published 16 February 2016

Copyright (C) 2016 by author and Scientific Research Publishing Inc.

This work is licensed under the Creative Commons Attribution International License (CC BY). http://creativecommons.org/licenses/by/4.0/

c) (i) Open Access

\begin{abstract}
The existing studies on the origin and history of mathematical economics are euro-centric and cover only the past two centuries. It is intended to show that 1) mathematical economics has an ancient origin. Kautilya wrote The Arthashastra during the fourth century BCE and used discrete marginal analysis and combinatory rules to sharpen economic analysis. 2) It is indicated that in the West, image of mathematics has changed directly and that of economics indirectly as the theology/philosophy of the church changed. 3) It is claimed that in India the developments in both economics and mathematics have always been simple, secular and user-friendly to solve problems related to agriculture, construction, navigation and trade.
\end{abstract}

\section{Keywords}

Combinations, Discrete Marginal Analysis, Mathesis, Metaphysics, Prospect Theory, Recursion and Iteration, Uclides

\section{Introduction}

In recent years, [1] Ingrao and Israel (1990), [2] [3] Mirowski (1989, 1991) and [4] Weintraub (2002) have explored why and how of the emergence of mathematical economics in the western world during the last two centuries. These works have been reviewed extensively and have generated both heat and light. Unsurprisingly all of them are Euro-centric. Weintraub argues that the image of economics changed as the image of mathematics changed but without realizing that the image of mathematics in the west might have changed with the change in the theology/philosophy of the church. It sounds strange but logically that means that the image of economics has changed as the theology/philosophy of the church changed. Economics has been criticized for lack of bon-

\footnotetext{
*It is a revised version of the paper presented at HES conference on June 28, 2015. I am thankful to the participants for their helpful comments. I am grateful to Chandra Kant Raju for many helpful suggestions.
} 
homie but surprisingly no one has ever realized or criticized it for being religion-based.

First of all, mathematics and economics neither originated in the western world nor during the $17^{\text {th }}$ or $18^{\text {th }}$ century implying that the scope of current studies on the emergence of mathematical economics is very limited. According to [5] Seidenberg (1962), mathematics originated in India earlier than Babylonia, Egypt or Greece. ${ }^{1}$ Similarly, Kautilya was the first economist, who established economics as a separate discipline, developed a score of economic concepts and understood the economy as a system with its inter-linked elements (see [6] Sihag (2014)). ${ }^{2}$ [7] Kautilya's Arthashastra contains two parts: the exchange theory and the conflict theory but both use mathematics to enhance clarity of expression and statistical analysis for arriving at the best possible policy-decisions under risky situations and evaluations afterwords. ${ }^{3}$ Secondly, there existed some knowledge of astronomy (physics) in ancient India, but economics did not imitate its methodology.

Weintraub applies Corry's distinction between the body and the image of mathematics to economics and devotes his entire book to show that the image of economics changed as the image of mathematics changed. However, neither Corry nor Weintraub explores: why did the image of mathematics change? [8] Raju has researched this topic quite extensively. He links the changes in the image of mathematics in the west to changes in the theology/philosophy of the church. According to him, during ancient times, 1) mathematics was considered as "mathesis" and was thought to arouse the soul and make people virtuous to lead a "blessed life", 2) became useless during the dark age, 3) was resurrected as reasoning and proof during the middle ages and 4) changed to formal representation during the twentieth century. Section 2 summarizes Raju's findings and concludes with a major implication that economics in the west is religion-based.

On the other hand, mathematics in India has been developed to solve practical problems and its role and image have not changed since the Harappa Civilization (2600 BCE-1800 BCE). This is presented in Section 3. Kautilya applied discrete marginal analysis as a guide to maintaining parity with a potential adversary. ${ }^{4}$ In fact, Kautilya showed awareness of some elements of a prospect theory. These are presented in Section 4. Kautilya

${ }^{1}$ Seidenberg (1962, p. 515) observes, "Hence we do not hesitate to place the Vedic altar rituals, or, more exactly, rituals exactly like them, far back of 1700 BCE. To summarize the argument: the elements of ancient geometry found in Egypt and Babylonia stem from a ritual system of the kind observed in the Sulvasutras.”

Baudhayana has been acknowledged as the author of Śulbasütras. Jagat Pati Joshi (2008, p. 157) points out, "The structures reveal that the Harappans had a good idea of geometry, particularly mensuration. They had a scale based on the decimal system. For measuring bigger areas, they perhaps used ropes. Surkotada had yielded a charred rope. Incidentally, the earliest Vedic geometrical treatises on geometry are called sulba sutras, deriving their name from sulba which means rope.”

[19] Kazanas (2009, pp. 132-133) remarks, "Be it noted that karpasa is the only word for cotton in Sanskrit. It is found first in the sutra texts, in Gautama's $(1,18)$ and in Baundhayana's (16.13.10) Dharmasutra... Cotton cultivation appears only in the mature SSC, after 2600. Thus these sutra-texts can be placed at this period at the earliest, i.e., 2600.” SSC= Sarasvati-Sindhu Civilization also known as Harappa Civilization.

${ }^{2}$ [20] Mattessich (2000, p. 203) remarks, "Kautilya’s Arthashastra is not merely significant for only for business accounting but also government accounting, with some stretch of imagination it may be regarded as a forerunner of national income accounting since the ultimate purpose of Kautilya's work was to strengthen the economy of the entire nation.”

${ }^{3}$ Kautilya (p. 544) stated, "Events, both human and providential, govern the world (and its affairs). Acts of God are those which are unforeseeable and whose origin is unknown. If the cause is knowable and, hence, foreseeable, its origin is human. If an act of God results in (helping) the achievement of one's objective, it is good fortune; otherwise, it is misfortune. (Likewise,) any human action which increases one's wealth is a good policy; otherwise, it is a bad policy."

Sihag (2014, Chap. 5): “Analysis of Variance”: The above statement amounts to the specification of a regression model and separating the total variation (in the dependent variable, wealth) into explained and unexplained (random) components. According to Kautilya, a policy should not get credit for positive changes in wealth if that was due to random factors (he called them "good fortune"). Similarly, a policy should not be blamed if there were negative changes in wealth due to unfavorable random variables. It implies that Kautilya's goal was to explain and predict the changes in the dependent variable. It may be noted that the evaluation of a policy depends on the ability to explain and predict. Indeed, according to Kautilya, explanation and prediction were the most important values of a discipline.

Thus, his implicit regression model may formally be specified as follows:

$$
W=X \beta+\varepsilon
$$

where, $W$ = wealth, the dependent variable, $X=$ exogenous policy variables, which may be used to acquire wealth, $\varepsilon=$ random error (the acts of God). Incidentally, the most important assumption of regression analysis that the error terms are independent of the right hand side variables, $X$, that is, $\operatorname{Cov}(X, \varepsilon)=0$, is clearly satisfied in the above statement. Additionally, the Covariance $\left(\varepsilon_{t}, \varepsilon_{t-1}\right)=0$ since acts of God are likely to be independent of each other across different years. It is not claimed that he knew the implications of these assumptions.

Also see [21] Sihag (2013) for additional applications of statistical analysis.

${ }^{4}$ Philip Mirowski (1991fn 5, p. 149) observes, "However, the bare format of symbolic expression should not be confused with mathematical reasoning. A more satisfactory approach needs to take into account the subtleties of mathematical discourse: an article couched entirely in prose but concerned with an elaborate discussion of the use of mathematics in economics may make many profound mathematical points, whereas another article which includes an equation or two in a footnote as irrelevant window-dressing effectively has little or no mathematical content at all.” 
counted all possible choices before examining the pros and cons of each one of them. Section 5 presents two examples in which Kautilya used combinatory rules to list all possible options so that no option was left out and also the order in which to examine the implications of each option. Kautilya was somewhat aware of the functional relationships between variables. This is provided in Section 6. Final section provides some concluding remarks.

\section{Raju on Images of Mathematics in the West since $5^{\text {th }}$ Century BCE}

According to Weintraub (2002, p. 2). "If economics is intertwined with mathematics in the twentieth century, in order to understand the history of economics we need to understand the history of mathematics. However, the history of mathematics involves the history of both changes in mathematical knowledge and changes in the images of that mathematical knowledge. Thus in what follows I will refract economics through the prism of changing images of mathematics." He explains that the image of economics changed as the image of mathematics changed. But he does not explain why did the image of mathematics change? However, Raju explains why the image of mathematics has been changing in the west.

Mathematics as Mathesis from 500 BCE to 500 CE: According to [8] Raju, Socrates believed that 1) soul was immortal and 2) learning was mere recollection. He tried to prove that by asking questions related to geometry from an uneducated slave boy. 3) Socrates also believed that learning was essential to making people virtuous. 4) Mathematics was defined as "mathesis", that is, as learning and it incorporated eternal truths. 5) Mathematics was assigned the role of arousing the soul and making people virtuous. Apparently, mathematics had a metaphysical origin in the west and was not considered useful to science. From Socrates to Proclus study of mathematics was considered to arouse the soul and essential to a "Blessed life".

Darkest Inage of Mathematics from 500 CE to Crusade: The Christian priests tasted some power and riches during the reign of Constantine and aspired to have more power. According to Westfall (quoted in [8] Raju (p 77)), Newton pointed out, “It's plain therefore that not a few irregular persons, but ye whole clergy began at this time to be puft up, to set their hearts upon power and greatness more than upon piety \& equity, to transgress their pastoral office \& exalt themselves..." Socrates' belief of teaching mathematics to arouse the soul became a hurdle in their pursuit of power. They modified incarnation to resurrection, created fear in the minds of believers by introducing the concepts of heaven and hell and sin. There was no role left for mathematics in this modified theological doctrine. Christian mob burned the library in Alexandria. Hypatia, who tried to teach the elements was raped and lynched. Proclus was declared a heretic and the church banned the study of mathematics and philosophy. During the dark age of Christendom, the image of mathematics also became dark in the west.

Mathematics as Reasoning and Proof from Crusade to 1900: The church tried to convert people to Christianity by force but that did not work against the Muslims. So it modified its approach and thought of converting them by soft power, that is by reasoning. Accordingly, the church brought back mathematics but with a changed image based on its theological philosophy of reason. The church performed a miracle by creating Euclid out of uclides (translation from Arabic as: the key to geometry) and declared him as the author of Elements. Actually there is absolutely no evidence that there was a historical Euclid and the Elements, most probably, was written by Theon and his daughter Hypatia around $500 \mathrm{CE} .^{5}$ Elements was hailed as a paradigmatic shift in mathematics claiming that for the first time in human history, proofs were derived from a few axioms. Thus, there were two changes of Biblical proportions: one in the image of mathematics and second in church's theology. Although it was still metaphysical, [9] Jose Ferreiros (2005) incorrectly equates Gauss's image of mathematics to that of Plato. According to Plato, mathematics was supposed to arouse the soul. On the other hand, Gauss was following the "reasoning and proof" image of mathematics as propagated by Descartes.

Attempt to Rescue eternal truth during 1900-1950: Hilbert and others discovered that Elements contained some empirical means for proving certain theorems. As a consequence two things happened: first, image of mathematics as an eternal truth could not be sustained. Secondly, an attempt to replace eternal truth by consistency through formal mathematics also failed. The following Table 1 summarizes the changes in the image of mathematics.

\footnotetext{
[22] Raju (2014, p. 49) summarizes his finding as: "Euclid the geometer and Claudius Ptolemy the astronomer were pure fabrications, like the stories of the Copernican and Newtonian revolutions. And these are just examples of what was obviously a large-scale and systematic effort, spread over centuries.”

Such fabrications are still continuing. For example, [23] David E. Rowe (2001) remarks, "Euclid was reputed to have told King Ptolemy that there were "no royal roads" to mathematical knowledge (though many over the centuries seem to have thought that Euclid's Elements provided the path of least resistance).”
} 
Table 1. Images of mathematics in West over the last 2500 years.

\begin{tabular}{|c|c|c|}
\hline \multicolumn{3}{|r|}{ West } \\
\hline Time-period & Author & Image \\
\hline $\begin{array}{l}5^{\text {th }} \text { century BCE to } 4^{\text {th }} \\
\text { Century CE }\end{array}$ & Plato & $\begin{array}{l}\text { To arouse the soul, “God does Geometry”, as Eternal Truth, a priori } \\
\text { reasoning }\end{array}$ \\
\hline $5^{\text {th }}$ century CE & $\begin{array}{l}\text { Theon and his daughter Hypatia } \\
\text { and Proclus }\end{array}$ & Essential to a "blessed life" \\
\hline \multirow[t]{2}{*}{$5^{\text {th }}$ century CE to Crusade } & & “Anathemas against pre-existence” \\
\hline & Descartes & $\begin{array}{l}\text { "Reasoning and proof" to align with post-crusade Christian theology } \\
\text { of reason", Deductive proofs }\end{array}$ \\
\hline \multirow[t]{2}{*}{ Post-Crusade to 1900} & Newton & $\begin{array}{l}\text { "Mathematics as the perfect language in which God had written the } \\
\text { laws of nature" }\end{array}$ \\
\hline & Gauss & “God does Arithmetic”, still metaphysics \\
\hline $1900-1950$ & Hilbert & Failed Attempt to replace Eternal truth by consistency, formalism \\
\hline 1950-Present & & It is still metaphysical \\
\hline
\end{tabular}

Raju points out that the theologically based two-valued logic approach to mathematics cannot be justified as universal since it is religion-based and deductive proofs are not superior to empirical proofs. [8] He (p. 159) argues, "The Buddha, for example, used the logic of catuskoti (four alternatives. Likewise, his contemporary, Mahavira, and the Jains used a logic of three alternatives or perhaps-ism (syadavada). Many mathematical proofs today use a technique called proof by contradiction. These proofs would all fail with Buddhist or Jain logic.”

The above discussion may be summarized as that the image of mathematics in the west has changed as the theology/philosophy of the church changed and it still has religious bias. Logically, that means that the image of economics has changed as the theology/philosophy of the church changed, implying that economics also is religion-based.

\section{Unchanging Image of Mathematics since Antiquity in India}

"In all those transactions which relate to worldly, Vedic or other affairs, mathematics is employed. In the science of love, in economics, in music and in drama, in the art of cooking and similarly in medicine and in things like the knowledge of architecture, the science of computation is held in high esteem. Whatever is there in all the three worlds, which are possessed of moving and non-moving beings all that indeed cannot exist without mathematics.” [10] Mahavira (c817-c875).

Since antiquity, mathematics in India has been developed to solve practical problems related to agriculture, trade, construction, navigation and engineering to enrich human life materially, culturally and in developing rhythms for music. In fact, mathematician Mahavira claimed its usefulness to all areas of human activity. Interestingly, he included even the "science of love" perhaps he was referring to Kamasutra. Whereas, according to [11] Edna St. Vincent Millay, "Euclid alone has looked on beauty bare" No Indian mathematician has been so lucky to experience anything like that. They instead used mathematics to create beautiful and enjoyable structures. Irony is that there is no record of any historical Euclid and let alone seeing any beauty and still this fictitious story has been repeated a million times. Theon, the true author of the Elements was looking for a "blessed life" and not beauty, bare or clothed.

Mathematics and Construction: More than five thousand years ago, Sindhu-Sarasvati Civilization (known as Harappa Civilization) introduced standardized weights and measurements to facilitate trade. It developed mathematics to solve architectural and engineering problems. Bricks were designed to provide maximum stability to the structures. The dimensions of the bricks in inches were $11 \times 5.5 \times 2.75$, that is, in the ratio of 4:2:1. [12] Jagatpati Joshi (2008, p. 157) observes, "There are quite a few buildings in Mohenjodaro, Harappa, Lothal and Kalibangan which have steps. In the construction of steps on the stairs, one must know how to divide height and length in equal parts. The construction of such a structure involves summation, subtraction, multiplication and division of fractions, which the Harappans apparently used." He (p. 164) adds, "The Harappans followed the decimal system of measurement, which was used by the Indus masons."

Harappans devised astronomical calendars to monitor the arrival of monsoons. [13] Vahia and Menon (2013) 
conclude, "It can be safely assumed that astronomers in the intellectually advanced Harappan Civilization had detailed knowledge of positional astronomy." They add, "Finally, we should mention that since the Dholavira was an important centre of trade and commerce, keeping track of time would have been crucial, but to date no structures that absolutely served this purpose have been identified.”

Mathematics and Sanskrit: If mathematics is the language, then Sanskrit is the language of mathematics. [14] Rachel Hall (2007) observes, "The Search for ways to list and classify meters led to important mathematical discoveries: Pascal's triangle, the Fibonacci numbers, and even the rudiments of the binary number system. The discoveries of these structures in India predated those in the West, sometimes by several centuries.”6

Mathematics and Music: Rachel Hall (2007) notes, "They used recursion and iteration-essential computer programming techniques-to generate lists of rhythms. The fact that several authors solved the same problem in different ways reveals the depth of Indian mathematical development at the time. These discoveries also apply to rhythm patterns in traditional and popular music." She adds, "The poetic meters that Pingala and Hemachandra studied have an analogue in music, and indeed, many of the rhythms used in classical Indian music have been deeply influenced by the meters of Sanskrit poetry.”

Kautilya wrote his Arthashastra during the fourth century BCE. He listed agriculture, trade and cattle-rearing as the three main enterprises at that time. Agriculture has been dependent on monsoon rains. An accurate prediction of the arrival of monsoon has been a top priority. Similarly navigation was essential to trade.

Mathematics and Navigation: [15] C. K. Raju (2011) summarizes his findings as: "To summarize the new history, the calculus originated in India for its practical value (for agriculture and navigation) and was brought to Europe also for its practical value (for navigation, and especially the problems of determining the three ells-loxodromes, latitude, and longitude).”

Development of mathematics in India has had no religious leanings and has been user-friendly to solve problems related to trade, agriculture, construction, navigation and music.

\section{Kautilya's Psychological Theory of Risk-Taking}

Kautilya criticized Yudhisthira, a crown prince, who lived around 3100 BCE, for his gambling habit. Yudhisthira put his kingdom, his four brothers, himself and his wife as wagers and lost all the bets. The whole family was exiled for 13 years. He was quite naïve in this game, did not win even a single hand and yet continued until he lost everything. [16] Sebastian Ebert and Philipp Strack (2015) call this "until the bitter end" and explain this by adopting the dynamic prospect theory. However, equally important question is: why did the winner also not stop? Kautilya offers a psychological explanation for this behavior.

Kautilya's Arthashastra is a manual on engineering Yogakshema-peaceful enjoyment of prosperity—for all the people. Kautilya argued that national sovereignty was essential to prosperity since a foreign ruler would be interested only in enriching himself, that is, prosperity and slavery were mutually exclusive. Then, he reasoned that prosperity was essential to guarding sovereignty since a poor nation could not have adequate resources to provide for strong national security, that is, for achieving and maintaining balance of power. Sihag (2014, Chap. 18) presents Kautilya's balance of power equation as follows:

$$
\begin{gathered}
P=A(J, H)(K)^{\lambda}\left(E L_{m}\right)^{(1-\lambda)} \\
R P_{1}=P_{E} / P_{C}
\end{gathered}
$$

where $P=$ power, $P_{C}$ and $P_{E}=$ powers of conqueror and potential adversary respectively, $A=$ efficiency parameter, $H=$ experience and analytical skills of the advisers in utilizing the information made available through intelligence, $K=$ horses, elephants, chariots and armaments, $E=$ enthusiasm and training, $L_{m}=$ military strength, $J$ = level of public support for a just and kind-hearted king and $R P_{1}=$ relative power of the potential adversary. Kautilya believed that $H$ was the most important factor in enhancing national security.

Kautilya on the Role of Expected Value and Variability: If the variability in yield on two pieces of land was the same, that is, $\sigma 1=\sigma 2$, then the decision should be based only on expected return. Kautilya (p. 619) stated,

\footnotetext{
${ }^{6}$ Not only mathematics originated in India but its development continued until the $17^{\text {th }}$ century. For example, [15] Raju points out, "The calculus had developed in India, over a thousand year period, from the $5^{\text {th }}$ to the $15^{\text {th }} \mathrm{c}$. for accurate calculations with planetary models, needed for the calendar - the key technology for monsoon-driven agriculture. It was used to obtain very precise trigonometric values (eventually to the $9^{\text {th }}$ decimal place). Precise trigonometric values were critical also for navigation.”

Similarly, [24] Struik asserts, "Ancient India may still yield many more mathematical treasures. We now know for instance, that the Gregory-Leibniz series for $\pi / 4$ can be found in a Sanskrit manuscript ascribed to Nilakantha (1500CE).”
} 
“As between two irrigated tracts, one on which cereals can be grown is preferable (7.11.5).” That is, $U\left(\mu_{1}, \sigma 1\right)>$ $U\left(\mu_{2}, \sigma 2\right)$ if $\sigma 1=\sigma 2$ and $\mu_{1}$ the expected return from the first piece of land $>\mu_{2}$, the return on the second piece of land.

Preservation of Wealth: Kautilya was farsighted as well as foresighted. He suggested preventive measures to reduce the probability of occurrence of a calamity and to keep ready the remedial measures, if despite efforts, a calamity still occurred so that the loss was kept to the minimum. He suggested measures to prevent an attack by a foreign king, developed traffic codes to prevent accidents, establishment of industrial zones to prevent fires, appropriate measures to prevent famines, floods, fire and epidemics. Kautilya (p. 116) suggested, "In the interests of the prosperity of the country, a king should be diligent in foreseeing the possibility of calamities, try to avert them before they arise, overcome those which happen, remove all obstructions to economic activity and prevent loss of revenue to the state $(8.4 .50,8.5 .21)$.” Kautilya was focused on making tomorrow better than today and no wonder he incorporated risk-analysis into decision-making.

Expansion subject to Preservation: Kautilya (p. 108) observed, "By maintaining order, the king can preserve what he already has, acquire new possessions, augment his wealth and power, and share the benefits of improvement with those worthy of such gifts. The progress of this world depends on the maintenance of order and the [proper functioning of] government (1.4).”

He (p. 629) stated, “A conqueror, having assured himself about his superiority in power, place and time, shall first leave behind a third or a quarter of his army to protect his capital, the rear, the forest regions and the borders; he shall then march towards the enemy taking with him enough wealth and forces to help him achieve his objective (9.1).” Kautilya wanted territorial expansion but subject to the preservation of existing territory.

(1) Loss-aversion: Kautilya put heavier weight on a loss than on an equal size of gain when taking risky decisions. He (p 634) surmised, "A small revolt in the rear outweighs a large gain in the front; for, when the king is not there, a small revolt in the rear may be worsened by the anger of the people or by traitors, enemies and jungle tribes. If this happens, a large gain in front, even if actually obtained, will be eaten up by the subjects, allies, losses and expenses. Therefore, a king shall not undertake a campaign when the gain in front is [less than] a thousand times the likely loss due to a revolt in the rear or, at least, a hundred times the loss. A well-known proverb is: 'Misfortunes are, [in the beginning] no longer than the point of a needle' (9.3)."

(2) Emphasis only on Marginal Gains and Losses: Kautilya considered power almost perfectly correlated with prosperity since he believed that a richer country could afford a stronger national security. He expected the king to be very vigilant and must keep parity with a potential adversary. He (p 554) explained, "It is a decline for the conqueror if the enemy's undertakings flourish; conversely, the decline of an enemy's undertakings is progress for the conqueror. Parity between the two is maintained when both make equal progress. A small gain for a large outlay is decline; the converse is progress. A gain equal to the expenditure on an undertaking means that the conqueror has neither progressed nor declined. Hence a conqueror shall seek to obtain a special advantage by undertaking such works [as building forts] which would produce a large profit for a small expenditure (7.12).” Kautilya's advice to the conqueror was to undertake such projects where the net gain (Revenue-cost) was the largest. The above statement implies the following cases:

$R^{0}=W_{E} / W_{C}$, (initial reference point).

$R^{1}=\left(W_{E}+\Delta W_{E}\right) /\left(W_{C}+\Delta W_{C}\right)=R^{0}+\left(\Delta W_{E}-\Delta W_{C}\right) /\left(W_{C}+\Delta W_{C}\right)$.

Case (i) If $\Delta W_{C}=0$ and $\Delta W_{E}>0$, it is a decline in the relative position of the conqueror, that is, $R^{1}>R^{0}$.

Case (ii) If $\Delta W_{C}=0$ and $\Delta W_{E}<0$, it is a progress in the relative position of the conqueror, that is, $R^{1}<R^{0}$.

Case (iii) If $\Delta W_{C}=\Delta W_{E}$, there is no change in the relative position of the conqueror, then $R^{1}=R^{0}$.

Where $R^{0}=$ reference point (initial relative position), $W_{C}=$ Conqueror's own wealth and $W_{E}=$ enemy's wealth, $\Delta W_{C}$ and $\Delta W_{E}$ are the incremental changes in conqueror's and enemy's wealth respectively.

According to Kautilya, the king (conqueror) required $R P_{1}<1$ for maintaining sovereignty. Otherwise, there was always a risk of losing it. Kautilya (p. 624) stated, “The king may face dangers even from a trusted king of equal power, when the latter has achieved his objective. Even an equally powerful king tends to become stronger after the task is accomplished and, when his power has increased, becomes untrustworthy. Prosperity changes peoples’ minds (7.5).”

Two things are obvious from the above statement: Initially, the ally was of equal power (i.e., $\left.R^{0}=1\right)$ and was trustworthy. But after the ally acquired additional power by winning a campaign, $R^{1}>R^{0}$, according to Kautilya, 
he was likely to become untrustworthy. Why? Kautilya hypothesized that "Prosperity changes peoples’ minds”, implying that the ally might not keep his promise not to attack the conqueror, that is, his preferences might change (time inconsistency problem) and also (ii) after accomplishing the task, his aspiration level was likely to rise (a new reference point) and his attitude towards risk-taking would change and was likely to become more assertive. Incidentally, according to the prospect theory, ally was to the left of his new reference point, more like in the domain of loss and would be risk-acceptant. If one looks at the past rulers, Alexander, Napoleon or any other ruler, each win made him more assertive and he kept on attacking other states until he met his Waterloo (losing the battle). It implies that Alexander most likely lost the battle and that is why decided to return back.

Coercive Diplomacy: In this situation the conqueror was in the domain of loss. Kautilya advised the conqueror to take measures that would stop the ally to put his sight on conqueror's kingdom. Kautilya (p. 609) advised, "An ally who is likely to grow in power after defeating the enemy and thus become uncontrollable shall be embroiled in a conflict with his own neighbor and his own ally; or, a pretender in his family or an unjustly treated prince shall be encouraged to seize the throne; or such actions shall be taken as would oblige the ally to remain obedient, in return for help received (7.18.31-32).”

Kautilya on the Importance of Balance of Power: He advised, (p. 566): “The would be conqueror shall apply the six methods with the degree to his power. He shall make peace with an equally powerful or stronger king; he shall wage war against a weaker king. [He shall not wage war against a stronger king] because he who fights against a stronger king is crushed like a foot soldier fighting an elephant. A fight with an equal brings losses to both sides, just like the destruction of two unbaked mudpots hitting each other. Like a stone striking a mudpot, a more powerful king gains decisive victory over a weaker one (7.3.1-5).” According to Kautilya, balance of power, irrespective of the domain (loss or gain), should not be ignored.

We may summarize this section as that Kautilya was the first economist, who introduced discrete marginal analysis to offer practical advice. Secondly, he understood the concept of time inconsistency problem and suggested precautionary measures to protect against it. Thirdly, most likely Alexandra decided to return back to Greece because of losing the battle to an Indian king named Porus.

\section{Kautilya on Use of Combinations for Making Policy Choices}

Kautilya (p. 99) explained his approach to writing his Arthashastra as: "Easy to grasp and understand, free from verbosity, Kautilya has composed this treatise with precise words, doctrines and sense (1.1.19).” Mathematics was used for precision and not as an ornament. Similarly, he suggested that decisions must be guided by statistical analysis.

He knew how to calculate combinations. He listed conciliation, placating with gifts, sowing dissension and use of force as the four methods of dealing with conflicts. The first two may be classified under risk-averse and the last two would be put under coercive diplomacy. Balance of power equation could not be ignored. He (p. 115) suggested, "The methods can be used singly or in combination depending on the seriousness of the situation. There are four ways of using any one method, six ways of using any two at a time, four ways of using three at a time and one way of using all four simultaneously. Thus, there are fifteen ways of using the methods singly or in any of the possible combinations in the anuloma [natural] order. Likewise, there are fifteen ways of using them in the pratiloma [unnatural] order 9.7.73-77).” He, then, explained which policy was the appropriate one to a specific situation. For example, he indicated that using all the four methods simultaneously before considering other possibilities would be unnatural.

Another Illustration of the Use of combinations: Kautilya offered a lesson in human psychology to the king. According to him, the king should anticipate the nature of reaction from his advisers and take appropriate steps so that they would not rebel. Kautilya (1992, 636) explained, “The king becomes angry and the counselors afraid when a campaign, undertaken on the advice of the counselors, fails to produce the gain predicted by them, but leads to losses and expenses. Counselors frightened of punishment may rebel. When the king gains from a campaign, disregarding the advice of traitorous counselors, then too the king becomes angry and the counselors afraid that the successful king will kill them for giving wrong advice. This too may make them rebel. When a campaign undertaken on the advice of trustworthy counselors achieves the objective or when a campaign undertaken disregarding the advice of untrustworthy counselors fails, in both cases the net result pleases all.” Kautilya's ideas on the relationship between accepting advice from trusted or non-trusted advisers and success or failure of a campaign may be expressed by the following matrix: 
Matrix of anticipated reactions of (King, Advisers).

\begin{tabular}{|c|c|c|c|}
\hline \multirow{2}{*}{ Type of advisers } & \multirow{2}{*}{ Advisers' recommendation } & \multicolumn{2}{|c|}{ Outcome of the campaign } \\
\hline & & Success & Failure \\
\hline \multirow{2}{*}{ Trustworthy } & Proceed & $\begin{array}{l}\text { (Pleases, Pleases) } \\
\text { Case I }\end{array}$ & $\begin{array}{l}\text { (Enrages, Fearful) } \\
\text { Case II }\end{array}$ \\
\hline & Not to Proceed & $\begin{array}{l}\text { (Enrages, Fearful) } \\
\text { Case III }\end{array}$ & $\begin{array}{c}\text { (Pleases, Pleases) } \\
\text { Case IV }\end{array}$ \\
\hline \multirow{2}{*}{ Untrustworthy } & Proceed & $\begin{array}{l}\text { (Pleases, Pleases) } \\
\text { Case V }\end{array}$ & $\begin{array}{c}\text { (Enrages, Fearful) } \\
\text { Case VI }\end{array}$ \\
\hline & Not to Proceed & $\begin{array}{l}\text { (Enrages, Fearful) } \\
\quad \text { Case VII }\end{array}$ & $\begin{array}{c}\text { (Pleases, Pleases) } \\
\text { Case VIII }\end{array}$ \\
\hline
\end{tabular}

According to Kautilya, a king should be aware of the various possibilities so that he can anticipate the possible reactions of the advisers and take the necessary steps to retain these most prized employees. Particularly, he should focus on the possibility of Case II, failure of campaign despite a recommendation from trustworthy advisers and the possibility of Case VII, success of campaign carried out against the advice of untrustworthy advisers. Despite a failure in a campaign, a king should not be angry with the trustworthy advisers. Since not only might he suffer a significant loss of men and material due to the failure, but also might lose his trustworthy advisers, who might be afraid of the king. On the other hand, despite success he should be concerned about the untrustworthy advisers and win them back or remove them. Incidentally, the possibility of Case VIII is interesting since in this case the king could not blame the advisers for the failure since he ignored their advice. Therefore, he had no reason to be angry with them.

We may summarize the above analysis as that Kautilya's goal was to advise the king on realistic possibilities and not to display his knowledge of combinations. Therefore, he ignored the middle four possibilities since the king would not reject the advice of trustworthy advisers and similarly, he would not accept the advice of the untrustworthy advisers. The following quote by Wolters testifies to the practical application of Kautilya's analysis. [17] Wolters (p. 49) writes, "An inscription states that the 11th century Javanese king named Erlangga subverted his enemy's power "by the application of the means taught by" the author of The Arthashastra, the most famous of all Indian treaties on the policies of a successful mandala manager. The Arthashastra also contains many precepts useful for a would-be conqueror." (Wolters cites the inscription translated by B.R. Chatterji, History of Indonesia, p. 183, verse 29).

\section{Use of Functional Relationship by Kautilya}

It is noteworthy that he implicitly used functional relationships to make decisions. He identified the king, the ministers, the public, the fort, the treasury, the army and the ally as the key elements of a state. He compared the seriousness of calamities befalling on these various elements of the state. According to him, if all of these elements could not be protected, a ranking of their importance was essential for making choices. Kautilya (p. 126) stated, "When two elements are affected equally, they should be judged according to whether the damage is increasing or decreasing, so long as neither of them affects any other element."

A few remarks are in order. The initial impact on say element $X_{1}$ and $X_{2}$ was the same, that is $C X_{1}\left(t_{0}\right)=$ $C X_{2}\left(t_{0}\right)$. First, the above statement implies that if no other element was adversely affected, attend to the element where the marginal cost was increasing, compared to the one where the marginal cost was declining. That is if $M C X_{1}(t)>M C X_{2}(t)$, attend to the first element.

Second, if the calamity to one of these two elements affected the other elements adversely, then that element should be considered more serious. That is, he noted that for valid comparisons, all the damages (i.e. the full impact) caused by the various calamities should be included. Thus, if element $X_{2}$ adversely affected element $X_{3}$, that should be included in the cost. And if $M C X_{2}(t)+M C X_{3}\left(X_{2}(t)\right)>M C X_{1}(t)$, attend to the second element first.

Third, the very fact that Kautilya made a point by implicitly using a functional relationship is significant. This is particularly significant, since it took the practitioners of the craft more than two thousand years to do so again. As [18] Scherer (2001) remarks, "The classical economists such as Adam Smith, David Ricardo, Robert Turgot and John Stuart Mill were not inclined to reason in functional terms, let alone in terms of specific volumedependent cost functions." It may be added that sometimes we fail to appreciate the efforts involved in developing even simple concepts, such as, functions. 


\section{Conclusion}

In an attempt to make mathematics perfect to conform to the image of God, it has become so complex that majority of the students cannot understand it and are turned off. As a result, they do not get the opportunity to appreciate and use it to solve practical problems. Perhaps, some cost-benefit analysis regarding the continuance of formal mathematics is called for, that is, a choice has to be made whether to serve the students or keep serving the church. On the other hand, since ancient times, mathematics in India has been utilitarian in nature. Mathematical proofs and theorems were not considered as aesthetically pleasing, rather mathematics was used to create aesthetically pleasing music and architecture. Mathematical proofs, unlike the deductive ones, are simpler. Kautilya understood the importance of mathematics in sharpening his economic analysis. He showed that it was possible to do meaningful economic analysis without formal mathematics. Formal mathematics has scared many students away from sciences and may be doing the same thing to economics also.

\section{References}

[1] Ingrao, B. and Israel, G. (1990) The Invisible Hand: Economic Theory in the History of Science. MIT Press, Cambridge.

[2] Mirowski, P. (1989) More Heat than Light. Cambridge University Press, New York. http://dx.doi.org/10.1017/CBO9780511559990

[3] Mirowski, P. (1991) The When, the How and Why of Mathematical Expression in the History of Economic Analysis. Journal of Economic Perspectives, 5, 145-157. http://dx.doi.org/10.1257/jep.5.1.145

[4] Weintraub, E.R. (2002)How Economics Became a Mathematical Science. Duke University Press, Durham and London. http://dx.doi.org/10.1215/9780822383802

[5] Seidenberg, A. (1962) The Ritual Origin of Geometry. Archive for History of Exact Sciences, 1, 488-527. http://dx.doi.org/10.1007/BF00327767

[6] Sihag, B.S. (2014) Kautilya: The True Founder of Economics. Vitasta Publishing, New Delhi.

[7] Kautilya, V. (1992) The Arthashastra, Edited, Rearranged, Translated and Introduced by L. N. Rangarajan, Penguin Books, New Delhi, New York.

[8] Raju, C. (2013) Euclid and Jesus. Multiversity and Citizens International, Penang.

[9] Ferriros, J. (2005) Dogmas and the Changing Images of Foundations.

[10] Mahavira (850/1912) The Ganiita-sāra-sañgraha of Mahāvīrācārya with English translation and notes, by M Ranga Chariyar. Government Press, Madras.

[11] Millay, E.S.V. (1892-1950) Euclid Alone Has Looked on Beauty Bare. http://www.poemhunter.com/poem/euclid-alone

[12] Joshi, J.P. (2008) Harappan Architecture and Civil Engineering. Infinity Foundation and Rupa, Delhi.

[13] Vahia, M. and Menon, S.M. (2013) A Possible Harappan Astronomical Observatory at Dholavira. Journal of Astronomical History and Heritage, 16.

[14] Hall, R. (2007) Math for Poets and Drummers. http://www.sju.edu/ rhall

[15] Raju, C. (2011) Teaching Mathematics with a Different Philosophy_II, Calculus without Limits. Science and Culture, 77, 280-285.

[16] Ebert, S. and Strack, P. (2015) Until the Bitter End: On Prospect Theory in a Dynamic Context. American Economic Review, 105, 1618-1633. http://dx.doi.org/10.1257/aer.20130896

[17] Wolters, O.W. (1999) History, Culture, and Region in Southeast Asian Perspectives, Revised Edition. Cornell Southeast Asia Program, Ithaca.

[18] Scherer, F.M. (2001) An Early Application of the Average Total Cost. Journal of Economic Literature, 39, 897-901. http://dx.doi.org/10.1257/jel.39.3.897

[19] Kazanas, N. (2009) The Rgveda Pre-Dates the Sarasvati-Sindhu Culture. Aryan Invasion Theory, Fabrications and Fallouts, Vol. 1, Vivekananda Kendra Patrika, Vol. 40, 79th Issue.

[20] Mattessich, R. (1998) Review and Extension of Bhattacharya's Modern Accounting Concepts in Kautilya's Arthashastra. Accounting, Business and Financial History, 8, 191-209. http://dx.doi.org/10.1080/095852098330512

[21] Sihag, B.S. (2013) Kautilya's Arthashastra: The Origin of Statistical Economics during Fourth Century BCE. JRSA, 2, $1-14$. 
[22] Raju, C. (2014) Is Science Western in Origin? Multiversity, Medusa, Goa, India.

[23] Rowe, D.E. (2001) Looking Back on a Bestseller: Dirk Struik’s “A Concise History of Mathematics”. Notes on the AMS, 48, 590-592.

[24] Struik, D. (1987) A Concise History of Mathematics. 4th Edition, Dover Publications, Mineola. 